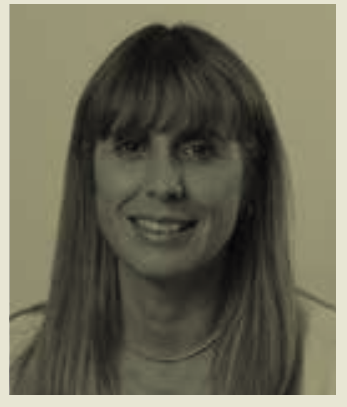

\title{
AVALIAÇÃO DE DESEMPENHO: POR QUE É TÃO DIFÍCIL?
}

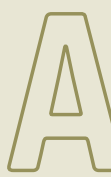

valiar e ser avaliado parecem tarefas difíceis para quase todos nós. Palavras como estressante, constrangedora ou até mesmo inútil vêm à tona quando se fala em avaliação de desempenho no trabalho. Parece ser ainda mais difícil para nós brasileiros, que gostamos de ser amáveis, estabelecer relações próximas e pessoais, preferimos evitar o conflito e, principalmente, o confronto, e acreditamos que possa haver um "jeitinho" para quase tudo.

Afinal, por que avaliar? Bem, do ponto de vista da organização, avaliar pressupõe "examinar e julgar" o resultado do trabalho realizado pelas pessoas para saber se estão desempenhando suas atividades de acordo com o esperado. No entanto, é bom lembrar que, para alcançar os efeitos desejados, a avaliação deve ser uma das etapas de um processo mais amplo, que compreende: estabelecer metas; monitorar e analisar o desempenho; dar e receber feedback e planejar e acompanhar as ações futuras para melhorar os resultados obtidos. Além disso, cada uma dessas etapas traz desafios: as metas devem ser claras, precisas e mensuráveis, bem como os critérios de avaliação; análises, feedback, planejamento e acompanhamento demandam tempo, que é sempre escasso. E não é difícil perceber que o produto de cada etapa será um dos inputs importantes para a fase seguinte, o que significa que todo o processo poderá ser comprometido caso haja alguma falha.

Existe a crença de que a avaliação ajuda o colaborador a crescer pessoal e profissionalmente, ou seja, um feedback honesto sobre o seu desempenho traz a oportunidade de melhorar e desenvolver competências. Entretanto, resultados negativos de uma avaliação também podem significar menores recompensas e poucas chances de promoção. Além disso, algumas pessoas podem apresentar dificuldades em estabelecer objetivos claros para sua vida profissional e, consequentemente, não conseguem saber, de fato, o que estão dispostas a "entregar" para a organização em termos de esforço, comprometimento e resultados. Portanto, é fácil perceber quão ambíguos podem ser nossos sentimentos em relação a sermos avaliados.

Como se pode observar, os desafios e obstáculos são muitos, mas é possível reduzir os problemas mediante à preparação dos envolvidos, não apenas em relação aos procedimentos formais do processo, mas, principalmente, em relação à (re)negociação do contrato que se estabelece entre colaborador e organização, ou seja, às expectativas de entrega de resultados e retorno.

Objetividade, clareza, disponibilidade, capacitação e vontade parecem ser essenciais para que um processo de avaliação traga resultados positivos. Quando falta algum desses atributos, os interesses e disputas pessoais, a criação de alianças e o favoritismo podem ganhar espaço. Assim, muitas vezes, as pessoas se engajam nesse processo apenas para "cumprir tabela" ou "fazer o que o RH pediu", limitando-se a preencher formulários, e o que poderia ser uma excelente oportunidade para uma genuína troca de expectativas, ideias e planos torna-se apenas mais um procedimento formal e burocrático. 